\title{
An Analysis of Factors Influencing Household Income: A Case Study of PACT Microfinance in Kyaukpadaung Township of Myanmar
}

\author{
Nem Nei Lhing ${ }^{1 *}$, Teruaki Nanseki ${ }^{2}$, and Shigeyoshi Takeuchi ${ }^{2}$ \\ ${ }^{1}$ Graduate School of Bio-resource and Bio-environmental Science, Kyushu University, Japan \\ ${ }^{2}$ Faculty of Agriculture, Kyushu University, Japan
}

\begin{abstract}
The study investigates factors influencing the household income of both clients and non-clients and effect of microfinance on clients' socioeconomic characteristics on establishing new enterprises. It uses Cobb-douglas functional form and Logistic regression model with a total sample size of 162 respondents [102 (clients) and 60 (non-clients)]. The empirical results from the model indicate that most common important influencing factor on household income is education. Educational level has a strongly positive impact on household income, suggesting that a client with a higher educational level can generate more income than one with a lower educational level. The results of the pool analysis show that six independent variables - age of the head of household, gender of the head of household, educational level of the head of household, land holding size, number of crops, and established new enterprise-have a significant influence on household income. We found that starting new enterprises is one of the most important factors for increasing the household income of clients. In order to establish new enterprises, the local government should pay more attention to the basic infrastructure requirement, market access facilities in the study area. Private Agency Collaborating Together (PACT) should focus on business training skills, apart from the provision of loans, to create sustainable microenterprises and other economic activities that increase the income of households.
\end{abstract}

Keywords: PACT, clients, non-clients, household income, Myanmar

\section{Introduction}

In Myanmar, most rural households find it difficult to finance their farming operations, including their other income-generating activities, owing to their limited savings. Therefore, in order to adopt relevant technologies and improve their farm productivity and income, the households need assistance in the form of production loans. The formal financial institutions in Myanmar (which are governmental financial institutions) are under the control of the Central Bank, and borrowers need to have assets or properties to get a loan from them. Consequently, the poor people in Myanmar are forced to avail credit facilities from certain rich people, brokers, and traders, who charged high interest rates. To solve this problem, the Private Agency Collaborating Together (PACT) microfinance program is introduced in 1997, with support from the United Nations Development Program (UNDP), to disburse loans in Myanmar's Dry Zone area. Currently, the microfinance program is implemented in 46 townships. The program proposes to cover over 385,000 clients in around 6,000 villages, $90 \%$ of them women MMIR (2010).

\footnotetext{
Corresponding author.
}

PACT is a non-governmental organization that provides finance without collaterals. The only requirement between the clients and the financing organization is trust.

A microfinance program is a type of loan assistance provided to economically vulnerable people to augment their household income by increasing investments in their enterprises, farming, and other income-generating activities. Many research findings in the literature are related to this study. For example, Maikasuwa (2012) found that participating in the program increased not only the earning capacity of borrowers but also their wealth. An analysis of the impact of microfinance on the income of beneficiaries by Nudamatiya (2010) showed that microfinance has a positive impact on the income of beneficiaries. Chua (2000) found that microfinance programs contribute to building all kinds of assets and lead to the diversification of sources of income for the participants. Rubana (2008) found that "microfinance institutions made increase income and consumption levels of households, reduce income inequality, and enhance welfare." The findings of Babajide (2011) based on the results of the Binary Logistic Regression Model, concluded that microfinance alleviated the financing difficulties of small enterprises.

ISSN 2167-9622 Print/ ISSN 2167-9630 Online / World Scholars http://www.worldscholars.org 
Although the above-mentioned research papers examined the effect of microfinance on household income and welfare using the socioeconomic indicators such as age, gender, education, and the value of household assets, they did not estimate the indicators that are important to increase household income. Although they used similar indicators to the ones used in this paper, they did not estimate all the variables examined in this paper at the same time and in one model. Therefore, we conducted two objectives on this paper. They are (i) to analyze the factors influencing household income of both clients and non-clients, and (ii) to estimate the effect of microfinance and clients' socioeconomic characteristics on establishing new enterprises.

\section{Review of PACT Myanmar Microfinance Program}

PACT is established in the United State in 1971 as an umbrella group to assist member NGOs. By 1992, PACT was not just an organization assisting member NGOs but was totally like an NGO, with the purpose of alleviating poverty around the world through local capacity building. PACT first entered Myanmar in 1997 and went on to manage the Dry Zone Microfinance Organization (DZMO), established under the UNDP's Human Development Initiative Program to provide loans to the vulnerable people to invest in incomegenerating activities Turnell (2005). The following figure (Figure 1) shows the source of funds for PACT Myanmar and the loan outflow to the clients.

\begin{tabular}{|c|c|c|c|c|c|c|}
\hline $\begin{array}{l}\text { UNDP/ } \\
\text { UNOPS }\end{array}$ & $\begin{array}{l}\text { Source of } \\
\text { Fund }\end{array}$ & $\begin{array}{l}\text { PACT Myanmar } \\
\text { Microfinance }\end{array}$ & $\begin{array}{l}\text { Providing } \\
\text { loans }\end{array}$ & $\begin{array}{c}\text { Clients } \\
\text { (5 members in } \\
\text { each group) }\end{array}$ & Repayment & $\begin{array}{c}\text { If one cannot repay, } \\
\text { all the members are } \\
\text { responsible }\end{array}$ \\
\hline
\end{tabular}

Figure 1. The flow of the loans to clients.

Table 1. Sustainable microfinance by PACT Myanmar to improve the livelihood of the poor.

\begin{tabular}{llll}
\hline Items & & Units & Number/Amount \\
\hline Village Tracts Covered & & Numbers & 109 \\
Villages Covered & & Numbers & 311 \\
Number of Credit and Savings Groups & Numbers & 5,854 \\
& Male & Numbers & 560 \\
Number of Clients & Female & Numbers & 31,488 \\
& Total & Numbers & 32,048 \\
Savings Mobilized & & Kyats & $189,532,477$ \\
Number of Loans Disbursed & Numbers & 279,443 \\
Amount of Active Loans & & Kyats & $2,209,782,000$ \\
Loan Amount Disbursed & & Kyats & $12,692,990,000$ \\
& Principal & Kyats & $11,570,801,544$ \\
Amount of Repayment & Interest & Kyats & $2,464,198,266$ \\
& Total & Kyats & $14,034,999,810$ \\
Loan Outstanding & & Kyats & $1,122,188,456$ \\
Male-Female Client Ratio & Male & $\%$ & 2 \\
& Female & $\%$ & 98 \\
Yearly Repayment Rate & & $\%$ & 99 \\
Clients Completed NFBE Training & & Numbers & 29,833 \\
Institution Development Training & & Numbers & 1,487 \\
Record Keeping Training & & Numbers & 573 \\
\hline Source: PACT Office & & &
\end{tabular}

Source: PACT Office

Donor: United Nations Development Program (UNDP)/United Nations Office of Project Services (UNOPS)

Table 1 reveals that the sustainable microfinance project to improve the livelihood of the poor is introduced in the dry zone area in 1997 by PACT Myanmar. The total number of villages operating in the microfinance program is 311 , with about 32,000 clients actively participating in the program, $98 \%$ of whom are female. PACT Myanmar has disbursed about 280,000 loans to the clients. As their record shows, the yearly repayment rate of the clients is
99\%. PACT Myanmar provides various kinds of training programs to clients, such as training in nonformal business education (NFBE), institutional development, and record keeping.

Turnell (2005) has mentioned that according to the PACT Myanmar microfinance rules, it takes three days for a group to get a loan. On the first day, the PACT Myanmar officials go to the village and announce the details of the loan in a meeting or at the 
village president's house. The PACT officials then call a meeting of the poor people in the village who are interested to avail a loan under the program. On the second day, the PACT officials form groups of the interested borrowers comprising five members each. If the groups are in an unstructured form, the PACT officials act as facilitators. On the third day, every group has to select its group leader and the treasurer, who would manage their savings. After that, the PACT officials disburse the loans. For repayment of the loans and interest, all the members of each group are responsible for each other. If a client cannot repay the loan, the rest of the members of the group will be responsible for the loan of that client. For a clear understanding of the procedure, the following figure (Figure 2) shows the process of loan disbursement to the clients.

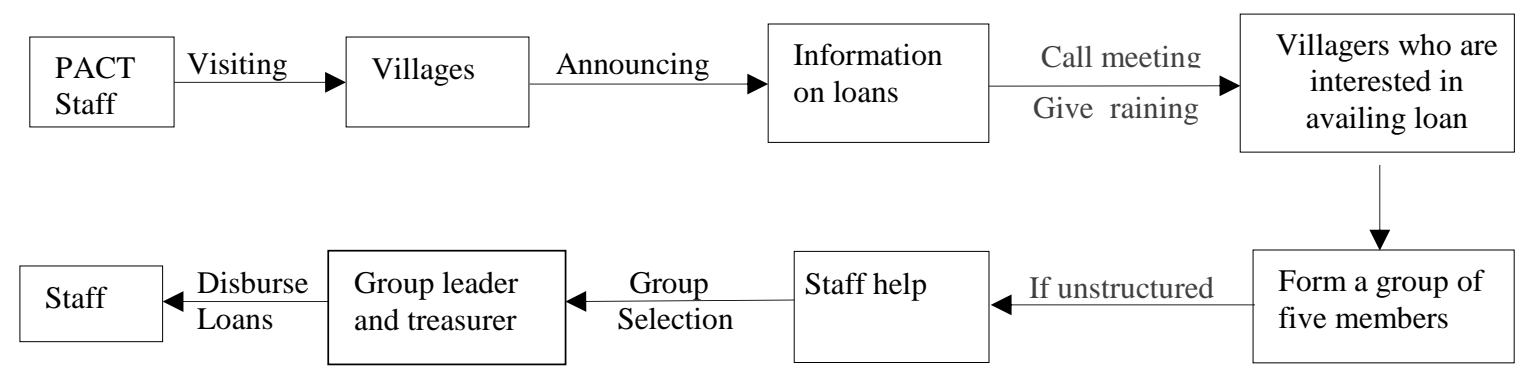

Figure 2. The process of loans disbursement to clients.

\section{Research Methodology}

\section{Study area}

The study is carried out in the Kyaukpadaung township area, Mandalay division, in the central part of Myanmar. The township has a total land area of 485,341 acres ( 1 ha $=2.4$ acres), and is composed of 339 villages with 109 village tracts and 78,935 households, $80 \%$ of them relying on agriculture. However, in the summer season when there is a drought, getting irrigation water for their crops is a problem in all the villages, and as a result, most of the households in the area invest their loans in small businesses or trade, especially in summer. The total population is about 394,674 , and about 268,703 acres of land are under cultivation. The area comprises 27,461 acres of lowland, 240,736 acres of upland, and 506 acres of other types of land. The annual average rainfall is 28.07 inches. The daily average maximum temperature is 41 degree Celsius, with an average minimum of 12 degree Celcius. There are two water irrigation sources for the township's summer rice cultivation, namely, the Kyetmaut and Pin dams. The major economic activities are agriculture and trade. Agriculture is by far the most important sector, with individual small holders being the most important production units MOAI (2008). Rice, pulses, sesame, groundnut, sugarcane, and certain horticulture crops are grown.

Table 2. Demographic information of the study area.

\begin{tabular}{lcccccc}
\hline Classification & Total & \multicolumn{3}{c}{ Under 18 years } & \multicolumn{3}{c}{ Above 18 years } \\
\cline { 2 - 7 } & households & Male & Female & Total & Male & Female \\
\hline Urban & 15,764 & 9,611 & 9,622 & 19,233 & 28,701 & 30,884 \\
Rural & 63,171 & 40,233 & 40,281 & 80,514 & 112,726 & 122,616 \\
Total & 78,935 & 49,844 & 49,903 & 99,747 & 141,427 & 153,500 \\
\hline
\end{tabular}

Source: Kyaukpadaung Township's Office.

\section{Survey design}

In October 2008, a survey is conducted in six villages in the Kyaukpadaung Township covering 162 households. Two strata of respondents were identified - those taking microfinance (clients), and those not taking microfinance (non-clients). Prior to data collection, the clients who had at least three years of experience as members of the program are interviewed. Data collection is done using the participatory approach, through questionnaires in a random-sampling face-to-face interview technique. The asking questions are very specific, with a fixed range of answers. Some of the questions had multiple-choice answers, and some had two response alternatives for the respondents; 102 responses are collected from the clients, and 60 , from the nonclients. 
The questionnaire also covered data on the household demographic and socioeconomic characteristics, such as age, household size, gender, assets, income, expenditure, health aspects, adoption of advanced technology, number of crops, participation in social activities, and establishing new businesses. For village information, the data are collected through the president of the village and members of the village committee, and for program information, the data are collected by interviewing the PACT microfinance program officials.

\section{Data analysis}

Data on the socioeconomic characteristics of the respondents are analyzed using descriptive statistics - the Cobb-Douglas (double-log) functional form and the Binary Logistic Regression Model.

(i) The Cobb-Douglas (double-log) functional form: it is used to identify the independent variables that are important factors for increasing household income.

$\log Y=\log a+b_{1} \log X_{1}+b_{2} X_{2}+\ldots+b_{10} X_{10}+e$ Where; $\mathrm{Y}=$ household income of respondents (annual income)

$\mathrm{X}_{\mathrm{i}}=$ independent variables $(\mathrm{i}=1-10)$

$b_{i}=$ estimated coefficients $(i=1-10)$

$\mathrm{e}=$ error term

(ii) The Binary Logistic Regression Model: it is used to estimate the effect of microfinance and clients' socioeconomic characteristics on establishing new enterprises.

$Z=\beta_{0}+\beta_{1} x_{1}+\beta_{2} x_{2}+\ldots+\beta_{10} x_{10}+\mu$
Where; $Z$ = establishing new enterprise (if the response is Yes, it is 1 ; otherwise, it is 0 )

$\mathrm{X}_{\mathrm{i}}=$ independent variables $(\mathrm{i}=1-10)$

$\beta_{i}=$ estimated coefficients $(i=1-10)$

$\mathrm{e}=$ error term

Table 3 explains the variables, codes, and the expected signs for each of the estimated coefficients and describes eleven independent variables - age of the head of household, gender of the head of household, marital status, education, household size, changes in farming practices, land holding size, number of crops, establishing new enterprises, participation in the program and household income. PACT Myanmar provides their clients with training in non-formal business education. After participating in the program, some of the clients could establish new small business enterprises such as tailor shops, motorcycle carriers, animal husbandry, vegetable shops, food shops, drug stores, drink stores, and horse carts. In the study area, male clients showed a preference for motorcycle carriers, animal husbandry, and horse cart businesses. On the other hand, females preferred to invest in businesses such as tailor shops, vegetable shops, food shops, drug stores, and drink stores. In this analysis, "gender of the head of the household" is an important factor. Even before this analysis, we expected that gender would be a significant factor because most of the clients in the study area are women owning small businesses, established with loans for income-generating activities. It would be interesting to analyze whether females make more money than males.

Table3. List of variables, codes, and the expected signs for the Cobb-Douglas and Logistic models

\begin{tabular}{|c|c|c|c|c|c|c|}
\hline & & & \multicolumn{2}{|c|}{ Cobb-Douglas } & \multicolumn{2}{|c|}{ Logistic Model } \\
\hline Independent Variables & Descriptions & Codes & & Signs & & Signs \\
\hline $\begin{array}{ll}\mathrm{X}_{1} & \text { Age }\end{array}$ & Age & Years & Age & $+/-$ & Age & $+/-$ \\
\hline Gender & Gender & Male $=1$, Female $=0$ & Gender & $+/-$ & Gender & $+/-$ \\
\hline MStatus & Marital Status & Married $=1$, Single $=0$ & MStatus & $+/-$ & MStatus & $+/-$ \\
\hline Education & Education & Years & Education & + & Education & + \\
\hline HHSizes & Household Size & Numbers & HSizes & + & HHSizes & $+/-$ \\
\hline CFPractices & $\begin{array}{l}\text { Change in Farming } \\
\text { Practices }\end{array}$ & Yes $=1, \mathrm{No}=0$ & CFPractices & $+/-$ & CFPractices & $+/-$ \\
\hline LHSizes & Land Holding Size & Number of acres & LHSizes & + & LHSizes & $+/-$ \\
\hline NCrops & Number of Crops & Numbers & NCrops & + & NCrops & $+/-$ \\
\hline $\begin{array}{l}\text { ENEnter } \\
\text {-prise }\end{array}$ & $\begin{array}{l}\text { Establishing New } \\
\text { Enterprises }\end{array}$ & Yes $=1, \mathrm{No}=0$ & ENEnterprise & + & (b) & (b) \\
\hline $\mathrm{X}_{10} \quad$ PProgram & Participation in Program & Client $=1$,non-client $=0$ & PProgram & + & PProgram & + \\
\hline $\mathrm{X}_{11}$ HHIncome & Household Income & Amount (US \$/year) & (a) & (a) & HHIncome & + \\
\hline
\end{tabular}

Notes: "(a)" denotes dependent variable for Cobb-Douglas (double-log) functional form

"(b)" denotes dependent variable for Binary Logistic Regression 


\section{Results and discussion}

Demographic and socioeconomic characteristics of clients and non-clients

For information on the demographic and socioeconomic characteristics of the clients and nonclients, see Table 4 . In terms of gender of the head of household distribution, $77.5 \%$ of the clients are female and $22.5 \%$ male. This agrees with the findings of Adebayo (1997), ADB (2000), Olomola (2001), and Adeyeye (2003). In the study area, the main participants of the program are female, indicating that the majority of program beneficiaries are female. This finding is in line with the work of Yunus Muhammad (1999), who stated that in Bangladesh's Grameen Bank - the biggest microfinance institution in terms of outreach-96\% of the clients are women.

In terms of age of the head of household distribution, the majority of clients $(50.0 \%)$ are within the $36-50$ age range, while $22.5 \%$ are younger. Thus, $72.5 \%$ of the clients are below 51 years, indicating that most of the clients in the microfinance program are young and active. These findings agree with those of Adinya (2011) that people under the age of 50 are economically more active and independent than those above the age of 50 years. For non-clients, only about $32 \%$ are aged below 51 years. For household size, while $57.0 \%$ of the client families has between one and five members, only $30.0 \%$ of non-client families has between one and five members. According to marital status results, while $98.3 \%$ of non-clients are married, only $64.7 \%$ of clients are married, indicating that the unmarried are more likely to join microfinance programs. The table also revealed that many of the clients have at least middle-level education, representing $42.4 \%$, while only around $22 \%$ of nonclients have the same level of education. The average household income of the clients and non-clients are, US $\$ 1090$ and US $\$ 939$ respectively. With regard to establishing new enterprises, 48 clients established new enterprises after participating in the program, while 14 non-clients already owned small enterprises.

The clients participated in the microfinance program for broadly the following reasons: the interest rates are low, collateral security is not required, the clients need loans, and they enjoy group financing. For non-clients, the reasons for not participating in the program include the following: they considered the procedures too complicated, feared legal action in case of default, are not interested in the program, did not need the loan, lacked information, and considered the loan terms unfavorable. From these findings, we can make some helpful suggestions and recommendations for the future programs, by adding or reducing some rules.

Table 4. Descriptive analysis for the demographic and socioeconomic distribution of respondents.

\begin{tabular}{|c|c|c|c|c|c|c|c|c|c|c|c|c|c|}
\hline \multirow[t]{2}{*}{ Variables } & \multirow[t]{2}{*}{ Measu: Items } & \multicolumn{6}{|c|}{ Clients $(\mathrm{N}=102)$} & \multicolumn{6}{|c|}{ Non-Clients $(\mathrm{N}=60)$} \\
\hline & & Freq & $\%$ & Avg & Max & Min & $\mathrm{CV}$ & Freq & $\%$ & Avg & Max & Min & $\mathrm{CV}$ \\
\hline & $\leq 35$ & 23 & 22.5 & & & & & 6 & 10.0 & & & & \\
\hline \multirow[t]{2}{*}{ Age } & $36-50$ & 51 & 50.0 & 47 & 71 & 26 & 190.08 & 13 & 21.7 & 52 & 77 & 35 & 133.02 \\
\hline & $\geq 51$ & 28 & 27.5 & & & & & 41 & 68.3 & & & & \\
\hline \multirow[t]{2}{*}{ Gender } & Male & 23 & 22.5 & 0.23 & 1 & 0 & 0.17 & 43 & 71.7 & 0.72 & 1 & 0 & 0.20 \\
\hline & Female & 79 & 77.5 & & & & & 17 & 28.3 & & & & \\
\hline \multirow[t]{3}{*}{ Marital status } & Married & 66 & 64.7 & 0.65 & 1 & 0 & 0.23 & 59 & 98.3 & 0.98 & 1 & 0 & 0.01 \\
\hline & Single & 36 & 35.3 & & & & & 1 & 1.7 & & & & \\
\hline & Illiterate & 18 & 17.6 & & & & & 13 & 21.7 & & & & \\
\hline \multirow[t]{3}{*}{ Educa -tion } & Primary & 29 & 28.2 & 2.97 & 4 & 1 & 1.147 & 31 & 51.7 & 2.27 & 4 & 1 & 1.182 \\
\hline & Middle & 43 & 42.4 & & & & & 13 & 21.7 & & & & \\
\hline & High & 12 & 11.8 & & & & & 3 & 4.9 & & & & \\
\hline \multirow{2}{*}{$\begin{array}{l}\text { House- hold } \\
\text { Size }\end{array}$} & $\leq 5$ & 58 & 57.0 & 5.49 & 12 & 1 & 9.69 & 18 & 30.0 & 7.18 & 13 & 3 & 5.00 \\
\hline & $>5$ & 44 & 43.0 & & & & & 42 & 70.0 & & & & \\
\hline Household & $0-800$ & 39 & 38.2 & & & & & 30 & 50.0 & & & & \\
\hline Income & $801-1600$ & 48 & 47.1 & 1090 & 3365 & & 3 4.294E5 & 20 & 33.3 & 939 & 2540 & 157.4 & $4.066 \mathrm{E} 5$ \\
\hline (yearly) US \$ & $>1600$ & 15 & 14.7 & & & & & 10 & 16.7 & & & & \\
\hline Establishing & new & & & & & & & & & & & & \\
\hline Enterprises & & 48 & 47.1 & 0.47 & 1 & 0 & 0.252 & 14 & 23.3 & 0.23 & 1 & 0 & 0.182 \\
\hline
\end{tabular}

Source: Adapted from Nem Nei Lhing (2009). 


\section{Factors influencing or the determinants of household income}

Before examining the results of both models, we first analyze the correlation between the variables. In the correlation matrix, most of the values of the variables are suitable to the analysis in the models. However, the values of two variables, education and changed farming practices, are 0.641 , indicating a moderate correlation between them. Although this study first analyzed all the variables in the models and then the nine variables excluding changed farming practices, the values of all the parameters and significant variables from both the results are the same. Therefore, we used all the variables to analyze in both models.

Table 5 shows the results of the independent variables that influence the household income of clients, non-clients, and both (combined clients and non-clients) using the Cobb-Douglas (double-log) functional form. From these results, we discuss the relationship between the dependent and independent variables as follows:

(i) For the clients' analysis, we examine nine independent variables to analyze which of them are important factors on household income. The value of the adjusted $\mathrm{r} 2$ shows that about $80.0 \%$ of the independent variables are closely related to household income. For correlation, the independent variables such as gender, marital status, education, household size, land holding, number of crops, and establishing new enterprises are positively correlated with household income. However, two variables, age of the head of household and change in farming practices, are negatively correlated with household income. For significance, three independent variables such as gender of the head of household, educational level, and establishing new enterprises, are positively significant factors influencing household income. For age of the head of household, the factor has a negatively significant influence on household income: a $1 \%$ increase in age reduces the household income by $0.461 \%$. This finding agrees with the work of Kudi (2009), who studied the impact of the UNDP microfinance programs on poverty alleviation among the farmers in selected local government areas of Kaduna State, Nigeria. Their study found that a unit increase in age would reduce household income by $31.5 \%$. The gender variable has a significant positive relationship with household income: male clients recorded higher household income than female clients did. This effect is significant at the 5\% level. The clients' educational level is critical and statistically significant for enhanced household income. As shown, a $1 \%$ increases in the education of the client will increase the household income by $0.191 \%$. This finding agrees with the work of Oluwasola (2010), who studied the stimulation of rural employment and income for cassava processing farming households in Oyo State, Nigeria. The author found that a unit increase in the level of education would increase the net income of clients by $29.5 \%$. In addition, this study shows that a $1 \%$ increase in establishing new enterprises will increase the household income by $0.269 \%$, as the variable is positively correlated with high statistical significance.

Table 5. Analysis of factors influencing the household income of clients and non-clients.

\begin{tabular}{|c|c|c|c|c|c|c|}
\hline & \multicolumn{2}{|l|}{ Clients } & \multicolumn{2}{|c|}{ Non-clients } & \multicolumn{2}{|c|}{ Both (Clients and Non-clients) } \\
\hline & Double-log & t value & Double-log & t value & Double-log & t value \\
\hline Constant & $9.521 * * *$ & 11.022 & $4.507 * * *$ & 3.553 & $6.393 * * *$ & 11.654 \\
\hline Age & $-0.461 * * *$ & -4.491 & 0.074 & 0.812 & $-0.228^{*}$ & 1.662 \\
\hline Gender & $0.124 * *$ & 2.472 & -0.011 & -0.127 & $0.144 * *$ & 2.138 \\
\hline MStatus & 0.067 & 1.164 & -0.104 & -1.459 & -0.016 & -0.190 \\
\hline Education & $0.191 * *$ & 2.334 & $0.538 * * *$ & 4.828 & $0.511 * * *$ & 7.011 \\
\hline HHSizes & 0.004 & 0.082 & $0.130 *$ & 1.753 & 0.013 & 0.256 \\
\hline CFPractices & -0.011 & -0.147 & -0.007 & -0.088 & -0.106 & -1.461 \\
\hline LHSizes & 0.061 & 0.973 & $0.248 * *$ & 2.353 & $0.227 * * *$ & 3.749 \\
\hline NCrops & 0.094 & 1.658 & 0.076 & 0.890 & $0.186^{*}$ & 1.942 \\
\hline ENEnterprise & $0.269 * * *$ & 3.255 & 0.164 & 1.588 & $0.460 * * *$ & 5.646 \\
\hline PProgram & - & - & - & - & -0.052 & -0.631 \\
\hline $\mathrm{r}^{2}$ & \multicolumn{2}{|c|}{0.817} & \multicolumn{2}{|c|}{0.774} & \multicolumn{2}{|c|}{0.758} \\
\hline Adjusted $\mathrm{r}^{2}$ & \multicolumn{2}{|c|}{0.799} & \multicolumn{2}{|c|}{0.733} & \multicolumn{2}{|c|}{0.742} \\
\hline $\mathrm{F}$ ratio & \multicolumn{2}{|c|}{$45.573 * * *$} & \multicolumn{2}{|c|}{$19.041 * * *$} & \multicolumn{2}{|c|}{$47.377 * * *$} \\
\hline $\mathrm{N}$ & \multicolumn{2}{|c|}{102} & \multicolumn{2}{|c|}{60} & \multicolumn{2}{|c|}{162} \\
\hline
\end{tabular}

Note: * **, *** Significant at 10\% (P< 0.1), 5\% (P< 0.05), and $1 \%(\mathrm{P}<0.01)$, respectively.

(ii) For the analysis of non-clients, nine independent variables are used, just as for clients. From the results, six independent variables (age of the head of household, educational level of the head of household, household size, land holding size, number of crops, and establishing new enterprises) have positive signs, while three (gender of the head of household, marital status, and changed farming 
practices) has negative signs. With regard to significance level, the variable for educational level is positive and highly significant at the $1 \%$ level, and is an important factor for influencing household income. Two variables, household size and land holding size, are also positively related to household income and significant at the 5\% and $10 \%$ levels, respectively. This implies that a $1 \%$ increase in household size and land holding will increase crop production and, at the same time, household income, by $0.130 \%$ and $0.248 \%$, respectively.

(iii) For the combined analysis, one independent variable (participation in the program) is added in the model to check whether the microfinance program has an impact on program participation or not. Thus, ten independent variables are used in the model to determine the variables influencing household income. This study showed that six independent variables have significant influence on household income. Except for the variable of age of the head of household, the other five variables such as gender of the head of household, educational level of the head of household, land holding size, number of crops, and establishing new enterprises, have significant positive influences on household income. This implies that a $1 \%$ increase in these variables will increase the household income by $5 \%, 1 \%, 1 \%, 10 \%$, and $1 \%$ significance levels, respectively. From the above three analyses, the variable for the educational level of the head of household is a common significant variable and the most important factor influencing household income. These findings indicate that the respondent with higher educational level can increase their household income rather than those with lower educational level.

\section{The relationship between establishing new enterprises and socio-economic factors}

We used the Binary Logistic Regression Model to estimate the effect of microfinance and socioeconomic characteristics on establishing new enterprises. Table 6 shows that the parameter estimates of the significant variables are as described in Equation 2. In the model, we analyzed ten independent variables using the Binary Logistic Regression Model to estimate their relation with establishing new enterprises. The overall fitness measure of the model is given by the likelihood value (-2 log likelihood), which shows how well the model fits the data. In this study, the value of $-2 \log$ likelihood is 61.76 , indicating that the data fit the model well, following Hair (1998), who mentioned that the smaller the value of $-2 \log$ likelihood, the more well-fitting the model.

In this analysis, the probability of the model chisquare (158.539 and Sig .000) is less than the significance level at 0.05 . It is hypothesized that the coefficient of the independent variables is equal to zero with the degree of freedom 10. This supports the existence of a relationship between the independent variables and the dependent variable. The fitness of the model was also determined using the Cox and Snell ( $\mathrm{r} 2=0.624)$ and the Nagelkerke $(\mathrm{r} 2=0.841)$ methods. The Nagelkerke $\mathrm{r} 2$ can be explained to mean that $84.1 \%$ of the variation in establishing new enterprises is owing to the independent variables in the model.

The direction of change in the probability of establishing new enterprises in relation to the independent variables can be explained according to the sign of the coefficients. In Table 6 , three out of ten independent variables strongly favor the odds of establishing new enterprises, because the value of the odds of these variables are greater than one and significant. These variables are household income, changed farming practices, and program participation. More specifically, the odds of establishing new enterprises (Y) are positively related to program participation, household income, and changed farming practices; this finding indicates that the probability of improvement on establishing new enterprises increases with increases in program participation, household income, and changed farming practices. The coefficients of the three variables are statistically significant at the $5 \%, 1 \%$, and $5 \%$ levels, respectively.

Table 6. Binary logistic regression estimates of the effect of microfinance and clients' socioeconomic characteristics on establishing new enterprises

\begin{tabular}{lcrrrr}
\hline Variables & $\mathrm{B}$ & $\mathrm{S} . \mathrm{E}$ & Wald & Sig. & $\operatorname{Exp}(\mathrm{B})$ \\
\hline HHIncome $\left(\mathrm{X}_{1}\right)$ & $.007 * * *$ & .002 & 16.593 & .000 & 1.007 \\
Age $\left(\mathrm{X}_{2}\right)$ & -.068 & .042 & 2.660 & .103 & .934 \\
Gender $\left(\mathrm{X}_{3}\right)$ & .698 & 1.033 & .456 & .499 & .009 \\
MStatus $\left(\mathrm{X}_{4}\right)$ & -.315 & .983 & .102 & .749 & .730 \\
Education $\left(\mathrm{X}_{5}\right)$ & -.741 & .524 & 1.999 & .157 & .477 \\
HHSizes $\left(\mathrm{X}_{6}\right)$ & .120 & .127 & .888 & .346 & 1.127 \\
CFPractices $\left(\mathrm{X}_{7}\right)$ & $2.645^{* *}$ & 1.039 & 6.476 & .011 & 14.088 \\
LHSizes $\left(\mathrm{X}_{8}\right)$ & .068 & .096 & .510 & .475 & 1.071 \\
NCrops $\left(\mathrm{X}_{9}\right)$ & .002 & .339 & .000 & .995 & 1.002 \\
PProgram $\left(\mathrm{X}_{10}\right)$ & $2.451^{* *}$ & 1.228 & 3.982 & .046 & 11.600 \\
Constant & $-6.532^{*}$ & 3.396 & 3.699 & .054 & .001 \\
\hline
\end{tabular}

Note: *,**, *** Significant at $10 \%(\mathrm{P}<0.1), 5 \%(\mathrm{P}<0.05)$, and $1 \%(\mathrm{P}<0.01)$, respectively; $\mathrm{N}=162$,

-2 Log likelihood $=61.176$; Chi-square $=158.539 ;$ Cox and Snell R2 $=0.624$; Nagelkerke $\mathrm{r} 2=0.841$. 


\section{Conclusions and Recommendations}

In sum, microfinance is a type of financial service providing loans to the poor to help them increase their household income and economic welfare, acquire property and reduce poverty, and support their need for better livelihood. By participating in the microfinance program, the clients received loans to establish new enterprises based on their skills. The new enterprises helped some of them increase their household income, and many of them could gain better education for their children and improved household assets. This study aimed to analyze the factors influencing the household income of both clients and non-clients, and to examine the relationship between establishing new enterprises and the socioeconomic factors of both clients and non-clients. The Cobb-Douglas (double-log) functional form is applied to analyze the former and the Binary Logistic Regression Model is applied to examine the latter.

From the demographic and socioeconomic characteristics results, we found that most of the clients who participated in the program are young, female, and single; has a higher educational level and higher average household income; and on average had established more new enterprises than nonclients. From the results of three regression analyses, we found that the most common important influencing factor on household income is education. Educational level has a strongly positive impact on household income, suggesting that a client with a higher educational level can generate more income than one with a lower educational level. The results of the combined analysis show that six independent variables - age of the head of household, gender of the head of household, educational level of the head of household, land holding size, number of crops, and established new enterprise- have a significant influence on household income. Out of these, gender of the head of household, educational level of the head of household, land holding size, number of crops, and establishing new enterprises significantly increased household income. However, the age variable significantly decreased household income. From the logistic regression results, three variables, household income, changed farming practices, and participation in the program, have a positive and highly significant impact on establishing new enterprises.

From the above results, we found that starting new enterprises is one of the most important factors for increasing the household income of clients. In order to establish new enterprises, the local government should pay more attention to the basic infrastructure requirement, market access facilities in the study area. PACT should focus on business training skills, apart from the provision of loans, to create sustainable microenterprises and other economic activities that increase the income of clients. The study area is located in Myanmar's Dry Zone area, where it is very difficult to grow crops in the summer owing to drought conditions. Therefore, the PACT program should provide effective training to open up more income-generating opportunities for the households, especially in the non-farm sector. The government also should collaborate with the microfinance organizations in this regard.

The major reasons for clients not participating in the program are the following: the procedures are too complicated, there is a fear of legal action, the program is not interesting, and there is a lack of information. Therefore, for non-clients, PACT should introduce easier and simpler loan procedures, reduce their exposure to legal action, and give attractive and more convincing information about the advantages of the program.

\section{References}

ACTED, (2010). Agency for technical cooperation and development. Banking With The Poor Network (BWTP Network), and Foundation for Development Cooperation, Myanmar Microfinance Industry Report, pp. 8-16.

ADB, (2000). Asian Development Bank. Finance for the Poor: Microfinance development strategy. Rural Asian Study: Beyond the Green Revolution, Manila, pp. 52.

Adebayo, A. A. (1997). The role of INGOs in poverty alleviation: A case study of farmers development union, Nigeria, pp.16-22

Adeyeye, V.A. (2003). Impact of Cooperative-based NGOs on Rural Poverty: A Case Study of Farmers Development Union in Osun State, Nigeria, No 10, Ibadan, pp.73.

Adinya, I.B., B.O. Offem \& G.U. Ikpi (2011). Estimation of efficiency constraints using Cobb-Douglas production function in snail production by small farmers in Cross River State, Nigeria, The Journal of Animal and Plant Sciences, 21(3), 595-600.

Babajide, A. (2011). Impact analysis of microfinance in Nigeria, International Journal of Economics and Finance, 3(4), 217225.

Chua,R.T., P.Mosley, A.N.Graham, Wright \& H.Zaman (2000). Microfinance, risk management and poverty, assessing the impact of microenterprise services (AIMS), USAID, pp.109.

Hair, J. F. Jr., W.C. Black, B. J. Babin, R. E. Anderson \& R. L. Tatham (1998). Multivariate data analysis (5th Edition), Upper Saddle River, NJ: Pearson/Prentice Hall.

Kudi,T.M., S.B. Odugbo, A.L. Banta \& M.B. Hassan (2009). Impact of UNDP microfinance programme on poverty alleviation among farmers in selected local government areas of Kaduna State, Nigeria. International Journal of Sociology and Anthropology, 1(6): 099-103.

Maikasuwa, M.A., A.L. Ala \& D. Mamoudou (2012). Impact of Irkoy Gomni micro-credit on poverty alleviation among cattle fatteners in Kollo Lga of Tillabery Region Niger Republic: Advances in Agriculture, Sciences and Engineering Research, 2 (5), 179-183.

MOAI, (2008). Ministry of agriculture and irrigation. Myanmar Agriculture in Brief, Nay Pyi Taw.

Nem, N.L., T. Nanseki, K. Hotta \& S. Shinkai (2010). An impact assessment of the performance of PACT microfinance program on rural households: Japanese Journal of Farm Management, 48(1), 124-129. 
Nudamatiya. A. B., D.Y. Giroh, \& J. F. Shehu (2010). Analysis of microfinance impact on poverty reduction in Adamawa State, Nigeria, Journal of Agriculture and Social Sciences, 6(4), 9195.

Olomola, A. S. (2001). The nature and determinants of rural loan repayment performance in Nigeria: The case of FADU's microcredit programme, 3: pp. 57.

Oluwasola, O. (2010). Stimulating rural employment and income for cassava processing farming households in Oyo State,
Nigeria, Journal of Development and Agricultural Economics, 2(2), 018-025.

Rubana, M. (2008). Micro financing in Bangladesh: Impact on households, consumption and welfare, Journal of Policy Modeling, pp. 1083-1092.

Turnell, S.R. (2005). A survey of microfinance institutions in Burma, Burma Economic Watch, pp. 23-45

Yunus, M. (1999). Banker to the poor: Micro-lending and the Battle against World Poverty, New York. 